\title{
THE IMPLEMENTATION OF QUALITY CONTROL MANAGEMENT FOR STUDENT GUIDANCE IN MAN 1 PAREPARE
}

\author{
Abdul Halik,' St. Wardah Hanafie Das² \\ 'State Institute for Islamic Studies (IAIN) Parepare, Indonesia \\ Jl. Amal Bhakti No.8, Bukit Harapan, Soreang, Parepare, South Sulawesi \\ E-mail: abdulhaliknas@gmail.com \\ ${ }^{2}$ Muhammadiyah University of Parepare, Indonesia \\ Jl. Jend. Ahmad Yani No.Km. 6, Bukit Harapan, Soreang, Pare-Pare, South Sulawesi \\ E-mail:wardahhadas@gmail.com
}

\begin{abstract}
The purpose of this study is to control the quality control of the guidance of the students, to minimize the quality control management barrier in the field of student guidance, and to formulate the applicative concept of the implementation of the quality control management field guidance of students in State Islamic Senior High School (MAN) 1 Parepare. This research method is case study at MAN 1 Parepare as the research object, data collecting technique are observation, interview, document study, triangulation, and Focus Group Discussion (FGD). Data analysis techniques are the identification and reduction of data, analysis, verification and conclusion. As results, MAN 1 Parepare has not applied quality management guidance and counselling learners. Barriers to the implementation of quality control management are limited human resources, insufficient infrastructure, limited budgets, uncompetitive learners, low external support, and limited partnerships. The implementation of quality control management of guidance and counselling field of students in MAN 1 Parepare is to carry out management functions in quality control, beginning with availability of quality standard system, quality procedure, quality audit, and quality control. The institutional requirements of the application of quality control management are the political will of the head of madrasah, the commitment and togetherness of human resources, the fulfilled infrastructure, the adequate budget, and the broad partnership.
\end{abstract}

Keywords: management; controlling; quality; teacher; institution.

\begin{abstract}
Abstrak: Tujuan dari penelitian ini adalah untuk mengontrol kualitas bimbingan siswa, meminimalkan hambatan manajemen kontrol kualitas dalam bidang membimbing siswa, dan untuk merumuskan konsep aplikatif dari penerapan bimbingan bidang manajemen kontrol kualitas siswa di Madrasah Aliyah Negeri (MAN) 1 Parepare. Metode penelitian yang digunakan adalah studi kasus, dengan objek penelitian sekolah MAN 1 Parepare, teknik pengumpulan data adalah observasi, wawancara, studi dokumen, triangulasi, dan Focus Group Discussion (FGD). Teknik analisis data adalah identifikasi dan reduksi data, analisis, verifikasi, dan penarikan kesimpulan. Penelitian ini dilaksanakan di MAN 1 Parepare. Sekolah ini belum menerapkan bimbingan manajemen mutu dan konseling peserta didik. Hambatan dalam penerapan manajemen pengendalian kualitas adalah sumber daya manusia yang terbatas, infrastruktur yang tidak memadai, anggaran yang terbatas, pelajar yang tidak kompetitif, dukungan eksternal yang rendah, dan kemitraan yang terbatas. Implementasi manajemen kontrol kualitas bidang bimbingan dan konseling siswa di MAN 1 Parepare adalah untuk melaksanakan fungsi manajemen dalam kontrol kualitas, dimulai dengan ketersediaan sistem standar kualitas, prosedur kualitas, audit kualitas, dan kontrol kualitas. Persyaratan institusional penerapan manajemen kontrol kualitas adalah kemauan politik kepala madrasah, komitmen dan kebersamaan sumber daya manusia, infrastruktur yang terpenuhi, anggaran yang memadai, dan kemitraan luas.
\end{abstract}

Kata Kunci: manajemen; pengendalian; kualitas; guru; institusi.

\section{Introduction}

A big responsibility of Indonesian government is a quality of education. The quality of education in Indonesia is low in elements of the education system itself, curriculum factors, ${ }^{1}$ personnel

${ }^{1}$ The learning design begins with the concept of a good curriculum that becomes a reference for conducting academic activities in school. The curriculum is considered less relevant 
resources, facilities and facilities, guidance and counselling management, education finance and leadership are factors that need to be examined. In addition, external factors such as low political participation, economic impartiality towards education, socio-culture, low utilization of science and technology, also affect the quality of education.

Quality is the target of achievement in the development of educational unit program and should always be evaluated to be known various problems and solutions. Act of the Republic of Indonesia Number 20, Year 2003 on National Education System (Sisdiknas), chapter XVI part one on the evaluation of article 57 paragraph 1 states that the evaluation is conducted in the context of the quality control of education nationally as a form of accountability of education to the parties concerned. Operationally, quality is determined by two factors, namely the fulfilment of predetermined specifications called quality in fact and the fulfilment of expected specifications according to the demands and needs of the service user called quality in perception ${ }^{2}$. Lickona 3 classifies indications of current adolescent tendencies, namely: (1) violence and anarchy; (2) theft; (3) fraudulent actions; (4) a waiver of the applicable rules; (5) brawl between learners; (6) intolerance; (7) the use of bad language; (8) too early sexual maturity and irregularities; (9) self-destructive attitude. The tendency of today's teenagers to be a big anxiety for parents and society, especially on the aspect of promiscuity, because teens seem free to do their wish without heeding the advice of parents.

in school because of students' psychic trends, social-cultural dynamics, and the progress of science and technology. See St. Wardah Hanafie das, Abdul Halik, Zulfianah Zulfianah, and Muh Naim. "Strategies of Islamic Education Teachers to Increase Students' Interest In Learning and Practicing in State Junior High School Lanrisang(SMPN) 1 Lanrisang, Pinrang." MADANIA: Jurnal Kajian Keislaman, vol. 22.no. 2 (2018), p. 254. See also Bambang Qomaruzzaman. "Religious Inclusivity in Islamic Education Course Book of the 2013 Curriculum." MADANIA: JURNAL KAJIAN KEISLAMAN, vol. 22, no. 2 (2018), pp. 195-210.

${ }^{2}$ Edward Sallis, Total Quality Management in Education: Manajemen Mutu Pendidikan, (Yogyakarta: IRCiSoD, 2012), p. 7.

3 Thomas, Lickona, "Educating for Character: How Our Schools Can Teach Respect and Responsibility" (New York: Bantam Books, 2009), 20-30, /z-wcorg/, http://search. ebscohost.com/login.aspx?direct=true $\&$ scope $=$ site $\& \mathrm{db}=$ nlebk $\& d b=$ nlabk\&AN $=721446$.
Transformation to be a best school begins by adopting a shared dedication to quality by school boards, administrators, staff, learners, educators, and the community. ${ }^{4}$

The vision of quality is focused on fulfilling the needs of customers, encouraging total community involvement in the program, developing a value-added educational measurement system, ${ }^{5}$ supporting the required system of staff and learners managing change, and continuous improvement by always striving to make educational products better. ${ }^{6}$ Therefore, urgent formulation of management development and quality control guidance learners at MAN 1 Parepare as an educational unit of Islam faces various challenges in the development of learners related to character and religion. The problem of learners appear on the symptoms of juvenile delinquency such as lack of discipline, even learning, indifferent to congregational prayers, lack of assistance in speaking, appreciation to teachers and seniors, and so forth.? These aspects are developed in the guidance and counselling of learners through quality control management in schools. Quality control management in the field of student guidance is needed in MAN 1 Parepare, to be more competitive in the community and other educational institutions.

Teachers in Islamic educational institutions must adjust to the requirement of the times. ${ }^{8}$

${ }^{4}$ The community is an educational stakeholder who has an interest in the success of education in schools. Abdul Halik, et al. "Empowerment of School Committee in Improving Education Service Quality at Public Primary School in Parepare City." Universal Journal of Educational Research 7.9 (2019), p. 1956.

${ }^{5}$ Secondary schools have a crucial role to provide the foundations for development of students' attitudes and personalities. Abdul Halik, Ms Suredah, and Mr Ahdar. "The Influence of Emotional and Spiritual Intelligence of Educator towards Learning Quality Improvement." 2018 3rd International Conference on Education, Sports, Arts and Management Engineering (ICESAME 2018), (Atlantis Press, 2018), p. 1.

6 Jerome S Arcaro, "Quality in Education: An Implementation Handbook," Terj, "Pendidikan Berbasis Mutu: Prinsip-Prinsip Perumusan Dan Tata Langkah Penerapan," (2007), p. 11.

${ }^{7}$ See. St Wardah Hanafie, et al. "Problems of Educators and Students in Learning Islamic Religious Education at MTs Pondok Darren Modern Darul Falah, Enrekang District." AlUlum, vol. 19, no. 2 (2019), p. 362.

8 Nuskhan Abid, "Penerapan Open Learning Course bagi Lembaga Pendidikan Islam (Analisis Persepsi Pengelola Pesantren di Kabupaten Kudus-Jawa Tengah)." MADANIA: JURNAL KAJIAN KEISLAMAN, vol. 21.no. 1 (2017), p. 49. 
It becomes a demand to control the quality so that MAN 1 Parepare still exist and survive in the community.

The purpose of the research to build awareness of MAN managers about the urgency of quality control management in the field of student guidance; minimize the barriers to the implementation of quality control management field guidance of learners in MAN 1 Parepare; to formulate the applicative concept of quality management implementation of the guidance field of students in MAN 1 Parepare; and develop the implementation format of quality control management field guidance learners at MAN 1 Parepare that can be a reference for other educational institutions.

As an organization, schools function to foster creative and innovative human resources not only the students but also the educators. The Urgent education paradigm is developed and oriented to build students' intellectual awareness by seeing various realities as potential forces that are important to be maintained. ${ }^{9}$ School organizations should be the right organizational model for all levels, from basic, intermediate, and high level. Improving the quality of education that has been pursued by the government through $\mathrm{MPMBS}^{10}$ should be accompanied also by the improvement of quality and improve school management. Educational managers are required to seek and implement quality-oriented management and continuous improvement ${ }^{11}$.

Quality is related to the issue of teacher ability, school readiness in supporting the learning process by providing the necessary facilities, and the educational support community ${ }^{12}$ in the

${ }^{9}$ Abdurrahmansyah, A. "Pendidikan Multikultural Dalam Desain Kurikulum dan Pembelajaran Keagamaan Islam, Madania: Jurnal Kajian Keislaman, vol. 21, no. 1 (2017), p. 80.

${ }^{10}$ The existence of MPMBS can give the school more creative in developing models and educational systems that are developed based on requirements and needs. See also Halik, Abdul. "Paradigm of Islamic Education in the Future: The Integration of Islamic Boarding School and Favorite School." Information Management and Business Review", vol. 8, no. 4 (2016), pp. 24-32.

11 Jam Jami and M Syukri, "Implementasi Manajemen Mutu Terpadu (Mmt) Di SD Negeri 03 Muara Pawan Kabupaten Ketapang," Jurnal Pendidikan Dan Pembelajaran Khatulistiwa, vol. 2, no. 4 (2015), p. 2.

${ }^{12}$ The articulation of educational urgency in a society region. Therefore, the effort to improve the quality of education should be closely linked with the efforts of empowering schools, educators, and the community in supporting education. Improving the quality of education cannot be done only by improving the curriculum, adding textbooks, and providing laboratories in schools ${ }^{13}$.

Management control system has elements, namely detector, selector, effector, and communicator. ${ }^{14}$ The detector looks for information about what is happening in the activity, the activity recorded in it compared to the standard or benchmark of criteria on what should be done and how far the need for justification. The refinement process is carried out by the effector, so deviations are changed so that the activity returns to the pre-set criteria. The implementation of the quality program required several strong foundations, namely: Commitment to change; Clear understanding of existing conditions; having a clear vision of the future; and a clear plan ${ }^{15}$. Awareness and insight of personnel is quite important meaning in carrying out the task consistently. Implementation of the quality of education program by adhering to the principles, namely focusing on customer, comprehensive involvement, measurement, education as a system, continuous improvement. ${ }^{16}$ Usman (2011) states the quality characteristics of education management in schools, is Performance (performance); Timeliness; Reliable (reliability); Durability; Beautiful (aesthetics); Human relations (personal interface); Easy to use (ease of use); Special form (feature); Specific standards (conformance to specification); Consistency; Uniform (uniformity); Able to serve (serviceability); and accuracy. These characteristics become the reference

is a "motor" that pushes for changing towards progress and glory. See Abdul Halik, "Paradigma Pendidikan Islam dalam Transformasi Sistem Kepercayaan Tradisional, " AL-ISHLAH: Jurnal Pendidikan Islam, vol. 14, no. 2 (2016), p. 141.

${ }^{13}$ Hujaimatul Fauziah, "Implementasi Manajemen Mutu Terpadu Dalam Rangka Meningkatkan Kepuasan Pelanggan Internal Di SMA Al-Kautsar Bandar Lampung," Jurnal Sains Dan Inovasi, vol. IV, no. 2 (Tahun, 2008), 93.

${ }^{14}$ Edy Sukarno, Sistem Pengendalian Manajemen: Suatu Pendekatan Praktis, (Jakarta: Gramedia Pustaka Umum, 2002), p. 3.

15 Nana Syaodih Sukmadinata, Pengendalian Mutu Pendidikan Sekolah Menengah, (Bandung: Refika Aditama, 2006), p. 9.

${ }^{16}$ Nana Syaodih Sukmadinata, Pengendalian.., pp. 12-13. 
and indicators in developing and controlling the quality of guidance of learners in school.

The details of components, subcomponents, and quality control of the guidance field of the learner, according to N.S. Sukmadinata ${ }^{17}$, are:

1. Planning guidance of learners:

a) Preparation of student development plan, including:

1) Plan of sports and arts activities;

2) Plan of Scout, PMR and Osis activities;

3) The plan of religious and social activities.

b) Making a plan of guidance and counselling activities, including:

1) Data collection (compilers record learners);

2) Education and teaching guidance;

3) career guidance;

4) Social and personal guidance.

2. Implementation of learning and guidance of learners

a) Implementation of guidance of learners, including;

1) Sports and art activities;

2) Scouting activities, PMR, and organizational learners;

3) Religious and civic activities.

b) Implementation of guidance and counselling services, including:

1) Data collection (compilation of record learners)

2) Education and teaching guidance;

3) career guidance;

4) Social-personal guidance.

3. Control of teaching and guidance of learners:

a) Evaluation and refinement of the implementation of student coaching, including:

1) Sports and arts activities;

2) Scouting activities, PMR, organizational learners, and others;

3) Religious and civic activities;

${ }^{17}$ Nana Syaodih Sukmadinata, Pengendalian.., pp. 54-59. b) Evaluation and refinement of guidance and counselling, including:

1) Data collection (compilation of learners record);

2) Education and teaching guidance;

3) career guidance;

4) Social and personal guidance.

The guidance of learners is very important in managing well, implemented systematically, clear measurement, and effective control. The quality control of the guidance of the learners is at least well documented for being the subject of ongoing evaluation and control in schools. Management control activities consist of various activities which include:

a. Plan what the organization should do;

b. Organizing the activities of various organizations;

c. Communicating information;

d. Evaluate information;

e. Deciding what action should be taken;

f. Influence people to change their behaviour ${ }^{18}$.

N.S. Sukmadinata, states that the steps taken in the implementation of quality control, namely:

a. Making a plan or work program.

b. Monitoring the implementation of activities, namely:

1) Monitoring of activities in class and practice room;

2) Monitoring of student coaching activities and counselling guidance;

3) Monitoring curriculum activities;

4) Monitoring of learning activities in the library;

5) Monitoring of internal and external data collection activities;

6) Monitoring of education information system development activities;

7) Monitoring of personnel development and development activities;

8) Monitoring the use of budget costs;

18 Robert N Anthony, Management Control: Sistem Pengendalian Manajemen, Transl," Kurniawan Cakrawala. (Jakarta: Salemba Empat, 2005), pp. 8-9. 
9) Monitoring of infrastructure development activities, and educational facilities;

10) Monitoring of external cooperation, service and relations activities;

11) Monitoring of student acceptance activities, follow-up study and graduate services.

c. Controlling analysis result

d. Improvement

The quality management program of the guidance field of the learner becomes an urgent part of the school. The program contributes greatly in improving learning achievement of students, both in terms of academic and nonacademic. ${ }^{19}$ The quality management program of the guidance field of the students should be holistic, continuous and well-planned, as planned and documented the results of the plan, implemented the program, then evaluated, the evaluation results are then controlled quality.

\section{Method}

The research approach used is qualitative that is studying and describing about quality control management field guidance of learners in MAN 1 Parepare. This approach is used with consideration of data obtained later in the form of descriptive data, the data as it is and not in the form of numbers ${ }^{20}$. Furthermore, this type of research is a case study, an activity that investigates to analyse and describe something in detail from the social phenomenon that occurs. The findings in the field, developed into a construct of quality control management system in the field of guidance of relevant learners applied in MAN 1 Parepare and other madrasah.

${ }^{19}$ Achieving the orientation and objectives above, There are five main steps fulfill the target of learning management activities, including: 1) managing the "atmosphere" of learning; 2) teaching task management; 3) teaching assignments management in the context of cognitive and affective; 4) presentation management in learning materials; and 5) productive environmental management. See Anwar Sewang, and Abdul Halik. "Learning Management Model of Islamic Education based on Problem: A Case Study of the Tarbiyah and Adab Department of IAIN Parepare." Journal of Talent Development and Excellence, vol. 12, no. 1 (2020), pp. 2731-2747.

20 Moh Kasiram, "Metodologi Penelitian: KualitatifKuantitatif,” (2010), p. 303.
Stages of this research begins with observation, preparation of research instruments, and data collection with observation, interviews, document studies, triangulation, and focus group discussion. The data obtained were analysed and piloted at a limited place and time, then evaluated and verified through FGD, and concluded. Data collection can be done in various settings, various sources, and various ways ${ }^{21}$. Data can be collected in natural settings such as conditions of quality management control implementation in MAN 1 Parepare, then from discussions and other scientific activities related to quality control management; data are collected in terms of sources, ie primary sources (direct data from MAN 1 head, supervisors, and educators) and secondary sources (data taken from MAN 1 Parepare administration documents and archives); then in terms of ways or techniques, data collected through observation, interview, and documentation.

Data analysis techniques used as applied Miles and Huberman, which is done in three flow of activities which is a unity (interrelated), namely; (1) word reduction; (2) data presentation; (3) withdrawal of conclusion / verification ${ }^{22}$. Qualitative analysis techniques are carried out for data taken from the field. Activity in qualitative data analysis is done interactively and progress continuously until complete, so that data is saturated (complete). ${ }^{23}$

\section{Result and Discussion}

Implementation of guidance and counselling management of learners in MAN 1 Parepare Guidance and counselling is the main task of madrasah (school) in developing the potential of learners. Improving the quality of education in madrasah cannot be separated from guidance and counselling programs to learners. The effectiveness of the learning process and implementation of the education curriculum in the madrasah is influenced by the extent of the readiness and willingness of learners. The

\footnotetext{
${ }^{21}$ Sugiyono, Metode Penelitian Kuantitatif, Kualitatif, Dan R\&D, (Bandung: Alfa Beta, n.d.), p. 224.

${ }_{22}^{2}$ Sugiyono, Metode Penelitian..., p. 307.

${ }^{23}$ Sugiyono, Metode Penelitian..., p. 249.
} 
academic achievement of learners is also closely related to non-academic achievement, such as achievement in extracurricular activities in schools. Therefore, academic and non-academic programs are important to be developed in madrasah (schools) to develop the physical and psychological potential of learners.

Student guidance and counselling management is very urgent and relevant to madrasah. Student guidance and counselling program needs to be well planned, in order to clear the direction and objectives, activity schedule, supporting factors and obstacles of the program can be identified, the strategy of achieving the objectives, empowering the resources owned, the evaluation system implemented, the prediction of the problems encountered and the solution, budgeting capabilities, and so forth. So is the organization of guidance and counselling programs is the mapping of responsibilities, coordination flow, schedule of activities, and so forth. Furthermore, the implementation of guidance and counselling program of learners should refer to the results of planning and organizing. Likewise in the evaluation, measurement and assessment of guidance and counselling programs of learners can be seen in aspects of processes and products.

Implementation of guidance and counselling management of learners in MAN 1 Parepare has not been implemented properly. Some are planned but not complete, not terminal, and well documented. Aspects reviewed in this paper are:

a. Student guidance planning:

Planning work program MAN 1 Parepare done at the beginning of each school year. Based on document study at MAN 1 Parepare, the principles of preparation of work program, especially in the field of guidance and counselling of participants, namely (1) the principle of relevance, namely epistemological relevance, psychological relevance, and sociological relevance; (2) flexibility principle, that is work program has flexible, flexible, and flexible in its implementation; (3) the principle of continuity, that is, the program is set up continuously within the stipulated time frame; (4) efficiency principle, that is program can utilize time, cost, and other resources optimally, meticulously, and appropriately; and (5) the principle of effectiveness, which is a program prepared for the effectiveness of the organization's work in performing the task and achieving the goal (study document MAN 1 Parepare, 2017). The following describes the planning of the field of coaching and counselling learners, namely:

1. Preparation of student development plan, including:

a) Plan of sports and arts activities;

b) Plan of Scout, PMR and OSIS activities;

c) Plan of religious and civic activity.

2. Preparation of guidance and counselling activities, including:

a) Data collection (compiler record of learners);

b) Education and teaching guidance;

c) career guidance;

d) Social and personal guidance

b. Implementation of guidance and counselling of learners

MAN 1 Parepare has been planning guidance and counselling of learners at the beginning of the new school year. Here is presented the implementation of guidance and counselling activities of students in MAN 1 Parepare, namely:

1. Implementation of the guidance of learners, including;

a) Sports and art activities;

b) Scouting, PMR and OSIS coaching activities;

c) Religious and civic activities.

2. Implementation of guidance and counselling services, including:
a) Data collection (compilation of record learners)
b) Education and teaching guidance;
c) career guidance;
d) Social-personal guidance.

3. Control of guidance and counselling of learners: 
a) Evaluation of the implementation of the guidance of learners, including:

1) Sports and arts activities;

2) Scouting, PMR and OSIS coaching activities;

3) Religious and civic activities;

b) Evaluation and refinement of guidance and counselling implementation, including:

1) Data collection (compilation of learners' records);

2) Education and teaching guidance;

3) Career guidance;

4) Social and personal guidance.

Based on the results of document studies, it is mentioned that each program used the instrument of process control or quality audit. Quality audits refer to high quality graduate standards, quality learning standards, internal rating/verification standards, service standards (SPM), intensive standards and financing, product and service standards, activity promotion standards, teacher and employee promotion standards, standards of activity and attendance, standards information and transparency, procurement and receiving standards, and document standards. This standard refers to the document study combined guidelines in improving the quality of guidance and counselling learners in MAN 1 Parepare.

Evaluation of work programs in the field of guidance and counselling of learners, based on informants' statement that "we do not have complete documents related to management guidance and counselling learners. We implement it based on repetitive habits and unless there is a new regulation from the government. "The informant's description confirms the document of the work program of MAN 1 principal 1 Parepare Lesson 2016/2017 related to quality control is normative, but the translation of sub-activities is not supported by a quality document that should be a reference for educators in MAN 1 Parepare.

Furthermore, information from other informants stated that: "As far as I know, we are here to foster learners in accordance with the habits, we nurture learners such as sports and art or organizational activities, we only carry out what we know, according to experience, and we do not see the standard of activity and achievement that should be the benchmark." The informant's description describes that the implementation of guidance and counselling of learners does not have operational guidelines and documented quality standards. Teachers work based on the knowledge, experience, and habits that developed so far in MAN 1 Parepare.

\section{Barriers to The Implementation of Guidance and Counselling Management of Learners in MAN 1 Parepare}

Guidance and counselling learners become effective when managed managerially. Effective management concepts on the guidance and counselling aspects of learners should be organized in a systematic and well-documented manner. Learners grow and advance if counselling and guidance management can be implemented effectively and efficiently. Based on observations and document studies in the field, guidance and counselling management of learners has not worked optimally, caused by some barriers, both internal and external. Here's the explanation.

\section{Internal barriers}

a. Human resources, whether in quantity, quality, or academic qualifications;

b. Learners, who are less constitutive because they are not selective in their acceptance;

c. Limited and fulfilling infrastructure, such as office buildings, activity halls, and sports fields;

d. Coaching budget is still very limited and has not been able to provide extracurricular costs to student organizations

Internal factors in MAN 1 Parepare is a problem that can be solved if supported by good planning. Budget in MAN 1 Parepare is for coaching learners, but the conditions of learners are different from other schools, which may require larger budgets. The condition of the learner, as described earlier, $50 \%$ of the orphanage, requires optimal student activity. This becomes one of the obstacles of guidance and counselling implementation in MAN 1 Parepare. 


\section{External barriers}

a. Partnership of external stakeholders, namely the limited partners by MAN 1 Parepare;

b. Support of parents and the community that is learners mostly immigrants from outside the region and the demographic schools are less representative.

The success of guidance and counselling in MAN 1 Parepare cannot be separated from the participation of parents and community. MAN 1 Parepare has an obstacle in involving parents and the community in improving the quality of learning and learners. Information from the head of MAN 1 Parepare, that "MAN 1 Parepare majority students from orphanages are automatically parents or guardians of the learners will not be active. Other students come from outside the area so that the involvement of the community around the madrasah is also not active. In another aspect, the domicile position of MAN 1 Parepare is less representative, ie hidden from the end of the road (alley), sheltered from STAIN Parepare campus, and located on a hill. "The description of MAN 1 Parepare's head is justified, however, other aspects of the barrier are less selective in the acceptance of new learners, receiving transfer of learners who have problems from other schools, school committee activity, and various other aspects. Parents and communities seem to have a gap with MAN 1 Parepare because of the above problems that became the main trigger.

Barriers experienced by MAN 1 Parepare in coaching guidance and counselling learners are quite principled. These obstacles can be resolved if there is optimal support from the Ministry of Religious Affairs, high community participation, managerial management of madrasah, and high dedication and professional from MAN 1 Parepare teacher.

Construct the implementation of quality control management guidance and counselling area of the students in MAN 1 Parepare MAN 1 Parepare as a madrasa adjacent to STAIN Parepare, should be a model madrassa as it often interacts with state universities. MAN 1 Parepare is required to have a commitment to improve the quality of education and learning, through a controlled and measurable system, excellent resources, commitment to togetherness, and broad partnerships. It should be the vision of MAN 1 Parepare to be more advanced, more trusted people, and more qualified as well as competitive alumni. MAN 1 Parepare has a great opportunity to become a leading and advanced madrasah, because it is close to academics and experts from STAIN Parepare lecturers.

Quality control management MAN 1 Parepare urgent and relevant initiated and conceptual and applied design. These quality demands are a priority of community assessment, competition from other schools, and gained the trust of the government. Related to the implementation of quality control management begins with the formulation of quality concepts and control procedures. Here is described the construct of implementation of quality control management field guidance and counselling learners on MAN 1 Parepare:

\section{Student guidance and counselling planning:}

Planning is the initial activity of decision making in order to work effectively and efficiently in achieving goals. Planning in general can be classified its scope, the objectives to be achieved, strategy achievement goals, resources support, and implementation of the decision. Goals to be achieved must be realistic, rational, and measurable. Strategy is the way and the steps that will be done in achieving the goal. Resources are potentials owned by institutions that can be empowered in implementing the program (strategy) in order to achieve goals effectively and efficiently. Implementation of the decision that is planned programs are applicative or operational.

Quality control management in the aspect of guidance planning and counselling learners need to be well designed and holistic. Areas of student guidance and counselling planning include: the objectives and targets to be achieved, the strategy of achievement, the budget required, the evaluation system used, the problems that may occur, alternative solutions to the problem, the schedule of activities, responsible activities, the infrastructure needed every activity, coordination 
and responsibility lines. Quality standard of planning activities also prepared the standard of quality planning, operational standards planning, quality planning standards, and planning quality evaluation. Each activity program has quality standards, operational standards, process standards, evaluation standards. Thus, the planning is elaborated with the complete standard of each activity program.

a. Preparation of student development plan, including:

1) The plan of sports and arts activities should refer to the quality standards of sports and arts activities, prepared operational standards, mapping of the field's quality achievements, and established a quality audit system;

2) The scout activity plan, PMR, and Osis, should refer to the quality standard of the student organization activity, the operational standard, the mapping of the quality achievement, and the quality audit system for the activity;

3) Religious and social plans should refer to the quality standards of religious and civic activities, set up operational standards, mapping of quality achievements, and establish a quality audit system for such activities.

b. Preparation of guidance and counselling activities, including:

1) Collecting data (compilers record students), should refer to the quality standards of student data collection, prepared operational standards, mapping of quality achievement, and established quality audit system of data collection learners.

2) Educational and teaching guidance, should refer to the quality standard of educational guidance and teaching of learners, prepared operational standards, mapping of quality achievement, and established quality audit system of educational guidance and teaching of learners.

3) Career guidance, should refer to the quality standard of the career guidance of learners, compiled operational standards, mapping of quality achievement, and set the quality audit system career guidance of learners.

4) Social and personal guidance, should refer to the quality standards of students' social and personal guidance, standardized operations, mapping of quality achievements, and the quality and social guidance of the learner's quality system.

The formulation of quality control management in the field of implementation starts from standard of activity quality, operational standard, standard of achievement (objective), document standard, budgeting standard, and activity control standard. Quality control management can be developed in MAN 1 Parepare, through the completeness of quality documents, support of internal and external stakeholders, commitment (political will) leadership of MAN 1 Parepare, willingness to make improvements and improvement activities for the future.

\section{Control of guidance and counselling of learners:}

Activity control is an evaluation and verification effort to be developed to become better from time to time, so as to achieve the objectives and generate satisfaction from stakeholders. Activity control is a commitment to improve quality continuously through evaluation or quality audit. The guidance and counselling activities of urgent learners are always evaluated and audited for the refinement of the intended activity. This becomes relevant because the condition of learners and their behavior is transformed, so there needs to be a change of the quality system in providing guidance and counselling services to the students. MAN 1 Parepare as a madrassa that has an 'ambition' to go forward, it is important to take policy to apply quality management system in guidance and counselling field of learners. Implementation of quality control management recommends improvement of managerial system of guidance and counselling activity of learners. In the 
aspect of planning, should be equipped with quality documents that become the reference and control in the evaluation and control. The implementation of quality audits on the implementation of activities always refers to the quality documents that have been set in the planning. Thus, quality control management is holistic, integral, dynamic, and flexible and oriented to stakeholder satisfaction. The field of quality control management system on evaluation and improvement aspects can be seen as follows:

a. Evaluation and refinement of the implementation of the guidance of learners, including:

1) Sports and arts activities should refer to standards of evaluation and quality control of sports and arts activities by learners, evaluation and quality control refers to operational standards, evaluates and compares between success and quality performance, and implements a quality audit system for improvement and improvement sports activities and the arts of learners in the future.

2) Scouting, PMR and OSIS guidance activities should refer to the evaluation standards and quality control of the student organization's guidance on students, evaluation and quality control based on operational standards, evaluate and compare between success and quality achievement, and apply quality audit system to improvement and refinement of student organization development activities to students in the future.

3) Religious and civic activities should refer to standards of evaluation and quality control of religious and civic activities on learners, evaluation and quality control refers to operational standards, evaluates and compares between success and quality performance, and implements a quality audit system for improvement and improvement religious and community activities to learners in the future. b. Evaluation and refinement of guidance and counselling implementation, including:

1) The collection of data (the compilation of students 'records), should refer to the standards of evaluation and quality control of students' data collection and management, evaluation and quality control referring to operational standards, evaluate and compare performance and quality achievement, and implement quality audit systems for improving and refining the activities of collecting and managing the data of learners in the future.

2) Educational and teaching guidance should refer to evaluation standards and quality control of educational and teaching guidance on students, evaluation and quality control refers to operational standards, evaluates and compares between success and quality achievement, and implements a quality audit system for improvement and improvement educational guidance and teaching activities to future learners.

3) Career guidance, should refer to standard evaluation and quality control of career guidance of learners, evaluation and quality control refers to operational standard, evaluate and compare between success and quality achievement, and apply quality audit system for improvement and improvement of career guidance activity of learners in the future.

4) Social and personal guidance, should refer to standards of evaluation and quality control of social and personal guidance on learners, evaluation and quality control refers to operational standards, evaluation and banding

Implementation of quality control management is very important in schools or madrasah. Guidance and counselling program of learners should be supported by components and related parties. Quality management functions in the field of guidance and counselling, ranging from planning, implementation, controlling (evaluating), 
to the control. Each program and activity should refer to the quality management function, and documented in the quality document. MAN 1 Parepare opens the opportunity to implement a quality control management system, with its own potential and challenges faced, it is recommended to take strategic steps to get there.

Construct the implementation of quality control management guidance and counselling of learners refers to the quality standard set by the Ministry of Religion RI and Ministry of National Education, using the concept and theory of quality management, and conditioned with the capacity and ability of MAN 1 Parepare. The quality standard in MAN 1 Parepare refers to effective national standards of education and bureaucratic management.

Characteristics of schools or madrasahs that have the trust of the community is a madrasah that implements a quality control management system. The community assesses effective madrasah if the program is measurable, transparent, information technology based, quality assured, extensive network of partnerships, customer-oriented, and best accredited. Quality control management is an institutional management system based on quality, transparency, future orientation, competitive, excellent service, and customer satisfaction oriented.

\section{Conclusion}

Management guidance and counselling of learners in MAN 1 Parepare have not managed well. Management functions in the field of guidance and counselling management of students have not been effective. The function of planning, examined guidance and counselling of learners but narrow and not detailed, the aspects of coaching and counselling has not been mapped clearly and firmly. Planning results are not found in the achievements of each program, implementation procedures, program evaluation systems, and are not documented. Likewise in the implementation aspect, lack of operational guidelines and technical guidance, evaluation aspect also found the same problem. Implementation of guidance and counselling management of students in MAN 1 Parepare has not been done properly, has not been discussed comprehensively, has not formulated implementation guidelines, and program evaluation system.

Obstacles in the implementation of guidance counselling management of learners in MAN 1 Parepare, namely: limited resources, unfilled building facilities, learners who have limited scientific capacity, budget guidance and counselling learners are far from enough, support stakeholders externals are very limited, and the participation of the community and parents of students who are not maximal. These barriers are specific, and barriers to other aspects are limited madrasah partnerships, madrasah facilities and infrastructure are very limited, the number of educators who are still honorary status, and management information system applications for learners have not existed. Problems experienced by MAN 1 Parepare there are internal factors and there are external factors. These two factors can be solved if there is involvement and participation from all related parties.

Implementation of quality control management guidance counselling field of learners in MAN 1 Parepare is very important. Head of MAN 1 Parepare urged to build political will and mind set of educators to think forward and dedicated in advancing madrasah. MAN 1 Parepare is important to develop quality standards that include quality standards, quality procedures, quality documents, and quality audits. The quality standard is adapted into the guidance and counselling management functions of the learners. Field of guidance and counselling activities of students equipped with quality field and adapted in management function. Completeness of aspects of quality control management, need to be supported by other requirements, namely togetherness and commitment of educators, utilizing information and communication technology, expand the network of partnerships, and oriented to excellent service and customer satisfaction

\section{References}

Abdurrahmansyah, A, "Pendidikan Multikultural Dalam Desain Kurikulum dan Pembelajaran Keagamaan Islam, Madania: Jurnal Kajian Keislaman,, vol. 21, no.1, 2017. 
Abid, Nuskhan, "Penerapan Open Learning Course bagi Lembaga Pendidikan Islam (Analisis Persepsi Pengelola Pesantren di Kabupaten Kudus-Jawa Tengah)." MADANIA: JURNAL KAJIAN KEISLAMAN, vol. 21, no. 1, 2017.

Anthony, Robert N, "Management Control: Sistem Pengendalian Manajemen, Terj." Kurniawan Cakrawala, Jakarta: Salemba Empat, 2005.

Arcaro, Jerome S,"Quality in Education: An Implementation Handbook, Terj." Pendidikan Berbasis Mutu: Prinsip-Prinsip Perumusan Dan Tata Langkah Penerapan, 2007.

Fauziah, Hujaimatul, "Implementasi Manajemen Mutu Terpadu Dalam Rangka Meningkatkan Kepuasan Pelanggan Internal Di SMA AIKautsar Bandar Lampung." Jurnal Sains Dan Inovasi, vol. IV, no.2, Tahun, 2008.

Halik, Abdul, Zulfianah Zulfianah, and Muh Naim, "Strategies of Islamic Education Teachers to Increase Students' Interest In Learning and Practicing in State Junior High School Lanrisang (SMPN) 1 Lanrisang, Pinrang." MADANIA: Jurnal Kajian Keislaman,vol. 22, no. 2, 2018.

Halik, Abdul, Ms Suredah, and Mr Ahdar, "The Influence of Emotional and Spiritual Intelligence of Educator towards Learning Quality Improvement." 2018 3rd International Conference on Education, Sports, Arts and Management Engineering (ICESAME 2018), Atlantis Press, 2018.

Halik, Abdul, et al, "Empowerment of School Committee in Improving Education Service Quality at Public Primary School in Parepare City." Universal Journal of Educational Research, vol. 7, no. 9, 2019.

Halik, Abdul, "Paradigma Pendidikan Islam dalam Transformasi Sistem Kepercayaan Tradisional." AL-ISHLAH: Jurnal Pendidikan Islam, vol. 14, no. 2, 2016.

, "Paradigm of Islamic Education in the Future: The Integration of Islamic Boarding School and Favorite School." Information Management and Business Review, vol. 8, no. 4, 2016
Hanafie, St Wardah, et al, "Problems of Educators and Students in Learning Islamic Religious Education at MTs Pondok Darren Modern Darul Falah, Enrekang District." Al-Ulum, vol. 19, no. 2, 2019.

Indonesia, Presiden Republik, “Undang-Undang Republik Indonesia Nomor 20 Tahun 2003 Tentang Sistem Pendidikan Nasional." Jakarta: Pemerintah Republik Indonesia, 2003.

Jami, Jam, and M Syukri, "Implementasi Manajemen Mutu Terpadu (Mmt) Di SD Negeri 03 Muara Pawan Kabupaten Ketapang." Jurnal Pendidikan Dan Pembelajaran Khatulistiwa, vol. 2, no. 4, 2015.

Kasiram, Moh, "Metodologi Penelitian: KualitatifKuantitatif," 2010.

Lickona, Thomas, "Educating for Character : How Our Schools Can Teach Respect and Responsibility." New York: Bantam Books, 2009. /z-wcorg/. http://search.ebscohost.com/ login.asp $x$ ?direct $=$ true $\&$ scope $=$ site $\& d b=$ nleb $k \& d b=n l a b k \& A N=721446$.

Qomaruzzaman, Bambang, "Religious Inclusivity in Islamic Education Course Book of the 2013 Curriculum." MADANIA: JURNAL KAJIAN KEISLAMAN, vol. 22, no. 2, 2018.

Sallis, Edward, "Total Quality Management in Education: Manajemen Mutu Pendidikan." Yogyakarta: IRCiSoD, 2012.

Sewang, Anwar, and Abdul Halik, "Learning Management Model of Islamic Education based on Problem: A Case Study of the Tarbiyah and Adab Department of IAIN Parepare." Journal of Talent Development and Excellence, vol. 12, no. 1, 2020.

Sugiyono, Metode Penelitian Kuantitatif, Kualitatif, Dan R\&D. Bandung: Alfa Beta, n.d.

Sukarno, Edy, Sistem Pengendalian Manajemen: Suatu Pendekatan Praktis, Jakarta: Gramedia Pustaka Umum, 2002.

Sukmadinata, Nana Syaodih, Pengendalian Mutu Pendidikan Sekolah Menengah, Bandung: Refika Aditama, 2006. 